\title{
Characterization of GnRH-related peptides from the Pacific oyster Crassostrea gigas
}

\author{
Laetitia Bigot $^{\mathrm{a}, \mathrm{b}}$, Céline Zatylny-Gaudin ${ }^{\mathrm{a}, \mathrm{b}}$, Franck Rodet ${ }^{\mathrm{c}}$, Benoit Bernay ${ }^{\mathrm{a}}$, Pierre Boudry ${ }^{\mathrm{d}}$, \\ Pascal Favrel ${ }^{\mathrm{a}, \mathrm{b}, \text { * }}$
}

\author{
a Université de Caen Basse-Normandie, IBFA, Biologie des Mollusques marins et des Ecosystèmes Associés \\ (BioMEA), 14032 Caen Cedex, France \\ ${ }^{b}$ CNRS INEE FRE 3484, BioMEA, France \\ c Université de Lille 1, Laboratoire de Spectrométrie de Masse Biologique Fondamentale et Appliquée, EA4550, \\ IFR 147, 59650 Villeneuve d'Ascq, France \\ ${ }^{d}$ Ifremer, Unité Physiologie Fonctionnelle des Organismes Marins, BP 70, 29280 Plouzané, France
}

\author{
*: Corresponding author : Pascal Favrel, Tel.: +33231565361 ; fax: +33 231565346 \\ email address : pascal.favrel@unicaen.fr
}

\begin{abstract}
:
Gonadotropin-releasing hormone $(\mathrm{GnRH})$, a key neuropeptide regulating reproduction in vertebrates has now been characterized in a number of non-vertebrate species. Despite the demonstration of its ancestral origin, the structure and the function of this family of peptides remain poorly known in species as distant as lophotrochozoans. In this study, two $\mathrm{GnRH}$-related peptides $(\mathrm{Cg}-\mathrm{GnRH}-\mathrm{a}$ and $\mathrm{CgGnRH}-\mathrm{G}$ ) were characterized by mass spectrometry from extracts of the visceral ganglia of the Pacific oyster Crassostrea gigas. These peptides showed a high degree of sequence identity with $\mathrm{GnRHs}$ of other mollusks and annelids and to a lesser extent with those of vertebrates or with $\mathrm{AKH}$ and corazonins of insects. Both the mature peptides and the transcript encoding the precursor protein were exclusively expressed in the visceral ganglia. Significant differences in transcriptional activity of $\mathrm{Cg}-\mathrm{GnRH}$ encoding gene were recorded in the ganglia along the reproductive cycle and according to trophic conditions with a higher level in fed animals compared to starved animals. This suggests the involvement of $\mathrm{Cg}-\mathrm{GnRHs}$ as synchronizers of nutritional status with energy requirements during reproduction in oyster. Evidence for a role of $\mathrm{Cg}-\mathrm{GnRH}$ s as neuroregulators and as neuroendocrine factors in bivalve is discussed.
\end{abstract}

\section{Highlights}

We characterized two GnRH forms in the oyster. Expression of GnRH peptides and encoding gene is specific to the CNS. Expression of GnRH gene depends of the reproduction and the nutritional status.

Keywords : Mollusk ; Bivalve ; Oyster ; Neuroendocrinology ; Reproduction ; GnRH 


\section{Introduction.}

Gonadotropin-releasing hormone $(\mathrm{GnRH})$ is a hypothalamic neuropeptide that plays a key role in the regulation of reproduction in vertebrates [11]. This neurohormone induces the release of the pituitary gonadotropins LH and FSH that stimulate gonad steroidogenesis and promote gametogenesis. With the identification of more than fourteen structural variants and three different forms of GnRH across various species of protochordates and vertebrates, it has become clear that GnRH peptides regulate various functions with neuroendocrine, paracrine, autocrine and neurotransmitter/neuromodulatory activities [27]. This wide distribution in the chordate lineage suggests that GnRH peptides and signaling pathways with conserved reproductive functions probably arose before the divergence between Deuterostoma and Protostoma [16] (for review). This early evolutionary origin was formerly proposed after the finding that yeast $\alpha$-mating factor shows some structural and functional similarity to GnRH [19].

Although the ancestral origin of GnRH-like peptides was clearly suggested by immunochemical and biological studies carried-out essentially in mollusks and cnidarians [10, $25,35,37]$, evidence came with the isolation and structural characterization of the first protostomian GnRH-like peptide from the cephalopod mollusk Octopus vulgaris [15]. This oct-GnRH is a dodecapeptide that deviates from the decapeptide motif possessed by all chordate GnRHs but displays the features characteristic to all GnRH molecules [34]. More recently, cDNAs encoding GnRH-like peptides were identified from the gastropod mollusks Aplysia californica [38] and Lottia gigantea as well as from the annelid Capitella [36]. Firm identification of GnRH-like peptides from Lophotrochozoa stresses the singular lack of GnRH peptides in Ecdysozoa, the second large clade of Protostoma including arthropods and nematodes, two phyla with considerable accessible genomic resources. The likelihood that GnRH would have been lost in Ecdysozoa was thus logically put forward [34]. Interestingly, a 
Caenorhabditis elegans peptide related to insect adipokinetic hormone (AKH) whose precursor displays similarities at the structural level with the AKH prepropeptides of arthropods and with the GnRH precursors of vertebrates [18] was found. Like its insect counterparts [31] this AKH-GnRH peptide binds a GnRH receptor orthologue. Interestingly, silencing of the genes encoding this peptide or its receptor induces a delay in the egg laying process in C. elegans [18]. This significant result supports the view of a role of the GnRH signaling system in the physiological control of reproduction in Protostoma, a point which remains a matter of debate [34].

Management of fertility is of crucial economical relevance for aquacultural species [26]. This is especially the case for the oyster Crassostrea gigas whose reproductive process has a major impact on several physiological functions, generating phenotypic and genetic trade-offs with growth and survival $[7,12]$. In this species, alternative splicing of a single gene generates multiple forms of Gonadotropin-Releasing hormone receptor orthologues expressed either specifically in the gonad or in a variety of tissues $[29,30]$. In line with the demonstration of co-evolution of ligand-receptor pairs [24]; one would expect some of these receptors to bind a GnRH-like peptide. Due to the recent development of genomic resources in C. gigas [8], we have identified two forms of GnRH-like neuropeptides $(\mathrm{Cg}-\mathrm{GnRH})$ from visceral ganglia of this bivalve mollusk using mass spectrometry. In addition, pattern of expression of $\mathrm{Cg}-\mathrm{GnRH}$ neuropeptides and their transcript was investigated using mass spectrometry or immunocytochemistry and RT-qPCR respectively.

\section{Materials and Methods.}

\subsection{Animals}

Two years old adult oysters Crassostrea gigas purchased from a local oyster farm (Normandie, France) were used for peptide characterization, transcription analyses and 
immunohistochemistry. Stages of reproduction (Stage 0: resting undifferentiated stage, Stage I: gonial multiplication stage, Stage II: maturation stage, Stage III: sexual maturity) were determined by histological analysis of gonad sections as described in [29]. To study the influence of trophic conditions, one year old adult oysters were reared in water tanks either in absence of food or with a $12 \%$ diet $(12 \%$ of oyster dry weight in algal (mixture containing Isochysis galbana (clone T-ISO), Chaetoceros calcitrans and Skelectonema costatum) dry weight per day) in controlled experimental conditions during 3 weeks. Adult mussels were obtained from commercial mussel farms from west Cotentin (Normandy, France).

\subsection{Extraction of tissues for peptide analysis}

Twenty animal equivalents of each organ studied (visceral ganglia, gonadic area, labial palps, digestive gland, mantle, mantle edge, muscles, gills) were extracted in $0.1 \%$ Trifluoroacetic acid (TFA) at $4^{\circ} \mathrm{C}$ and centrifuged for 30 minutes at $35,000 \mathrm{xg}$ at $4^{\circ} \mathrm{C}$. The supernatants were concentrated on Chromafix C18 solid phase extraction cartridges (Macherey-Nagel). Samples were evaporated for nano LC or HPLC purification.

\subsection{Nano-LC purification of visceral ganglia extract}

The chromatography step was performed on a nano-LC system (Prominence, Shimadzu). Peptides were concentrated on a Zorbax $5 \times 0.3 \mathrm{~mm} \mathrm{C18}$ pre-column (Agilent) and separated onto a ACE 50x0.5mm C18 column (AIT, France). Mobile phases consisted of $0.1 \%$ acetic acid, $99.9 \%$ water (v/v) (A) and $0.1 \%$ acetic acid, $20 \%$ water in $79.9 \% \mathrm{ACN}(\mathrm{v} / \mathrm{v} / \mathrm{v})(\mathrm{B})$. The nanoflow rate was set at $800 \mathrm{~nL} / \mathrm{min}$, and the gradient profile was as follows: constant $5 \% \mathrm{~B}$ for $5 \mathrm{~min}$, from 5 to $100 \% \mathrm{~B}$ in $75 \mathrm{~min}$, constant $100 \% \mathrm{~B}$ for $20 \mathrm{~min}$, and return to $10 \% \mathrm{~B}$. The $800 \mathrm{~nL} / \mathrm{min}$ volume of the peptide solution was mixed with $1.6 \mu \mathrm{L} / \mathrm{min}$ volume of a mix of $5 \mathrm{mg} / \mathrm{mL}$ CHCA matrix prepared in a diluting solution of $50 \% \mathrm{ACN}$ with $0.1 \%$ TFA. 
Fifteen second fractions were spotted by an Accuspot spotter (Shimadzu) on a stainless steel Opti-TOFTM 384 targets. MS experiments were realized on an AB Sciex 5800 proteomics analyzer.

\subsection{Mass spectrometry analysis}

MS analysis were carried out on an AB Sciex 5800 proteomics analyzer equipped with TOF TOF ion optics and an OptiBeam ${ }^{\mathrm{TM}}$ on-axis laser irradiation with $1000 \mathrm{~Hz}$ repetition rate. The system was calibrated immediately before analysis with a mixture of des-Arg-Bradykinin, Angiotenin I, Glu1-Fibrinopeptide B, ACTH (18-39), ACTH (7-38) and mass precision was above $50 \mathrm{ppm}$.

A $0.8 \mu \mathrm{L}$ volume of the HPLC fraction was mixed with $1.6 \mu \mathrm{L}$ volume of a suspension of CHCA matrix prepared in $50 \% \mathrm{ACN} / 0.1 \%$ TFA solvent. The mixture was spotted on a stainless steel Opti-TOFTM 384 targets; the droplet was allowed to evaporate before introducing the target into the mass spectrometer.

All acquisitions were taken in automatic mode. A laser intensity of 3000 was typically employed for ionizing. MS spectra were acquired in the positive reflector mode by summarizing 1000 single spectra $(5 \times 200)$ in the mass range from 600 to $4000 \mathrm{Da}$. MS/MS spectra were acquired in the positive MS/MS reflector mode by summarizing a maximum of 2500 single spectra $(10 \times 250)$ with a laser intensity of 3900 . For the tandem MS experiments, the acceleration voltage applied was $1 \mathrm{kV}$ and air was used as the collision gas. Gas pressure medium was selected as settings. The fragmentation pattern was used to determine the sequence of the peptide. Database searching was performed using the Mascot 2.3.02 program (Matrix Science) from a GnRH database elaborated with the software AASeq 5-2 (Zanuttini and Henry, http://zanutti.perso.info.unicaen.fr/aaseq/. This GnRH random library is built on the basis of the tags identified from Lophotrochozoan GnRH alignment (N-terminal pyroglutamate, amidation, consensus sequence $\left.\mathrm{S}_{7}-\mathrm{N}-\mathrm{G}-\mathrm{W}\right)$. The $\mathrm{MS} / \mathrm{MS}$ spectrum of the 
peptide is then screened by Mascott using the focused sequence database. The results were confirmed by screening the latest version of $C$. gigas "GigasDatabase" [8] (including $1,013,570$ entries) http://publiccontigbrowser.sigenae.org:9090/Crassostrea gigas/index.html. The variable modifications allowed were as follows: C-terminal amidation, N-terminal pyroglutamate, N-terminal acetylation, methionine oxidation and dioxidation. Mass accuracy was set to $100 \mathrm{ppm}$ and 0.6 Da for MS and MS/MS mode respectively.

\subsection{Mapping of GnRH by HPLC analysis}

HPLC analysis was performed with the software LC-STAR VARIAN connected to a VARIAN 9012 solvent delivery system and a VARIAN 9050 wave length UV-VIS detector set at $214 \mathrm{~nm}$. Tissue extracts were resuspended in $0.1 \%$ acetic acid and fractionated by HPLC onto a nucleodur C8 column (Macherey Nagel, $250 \times 4,5 \mu \mathrm{m}$ ) with a 45-min acetonitrile linear gradient of $1.33 \%$ per minute in $0.1 \%$ acetic acid. HPLC fractions coeluting with synthetic Cg-GnRH (GL Biochem, China) were evaporated for mass spectrometry analysis.

\subsection{Reverse transcription and quantitative PCR}

Real time RT-qPCR analysis was performed using the iCycler $\mathrm{iQ}(\mathrm{C}$ apparatus (Bio-Rad). Total RNA was isolated from adult tissues using Tri-Reagent (Sigma-Aldrich) according to the manufacturer's instructions. Recovered RNA was then further purified on Nucleospin RNAII columns (Macherey-Nagel). After treatment during 20 min at $37 \mathrm{C}$ with $1 \mathrm{U}$ of DNase I (Sigma) to prevent genomic DNA contamination, $1 \mu \mathrm{g}$ of total RNA was reverse transcribed using $1 \mu \mathrm{g}$ of random hexanucleotidic primers (Promega), $0.5 \mathrm{mM}$ dNTPs and $200 \mathrm{U}$ MMuLV Reverse Transcriptase (Promega) at $37 \mathrm{C}$ for $1 \mathrm{~h}$ in the appropriate buffer. The 
reaction was stopped by incubation at $70 \mathrm{C}$ for $10 \mathrm{~min}$. iQ ${ }^{\mathrm{TM}} \mathrm{SYBR}$ Green Supermix PCR kit (Biorad) was used for real time monitoring of amplification (5 ng of cDNA template, 40 cycles: $95^{\circ} \mathrm{C} / 15 \mathrm{~s}, \quad 60 \mathrm{C} / 15 \mathrm{~s}$ ) with the following primers: Qs-Cg-GnRH 5'AGCGTATTTCTGGCCGTACA -3' and Qa-Cg-GnRH 5'-CCATGCCCAAAATTACCACT $3^{\prime}$ as sense and antisense primers respectively. Accurate amplification of the target amplicon was checked by performing a melting curve. Using Qs-Cg-EF (5'ACCACCCTGGTGAGATCAAG-3') and Qa-Cg-EF (5'-ACGACGATCGCATTTCTCTT-3') primers, a parallel amplification of oyster Elongation Factor $1 \alpha$ (EF1 $\alpha)$ transcript (BAD15289) was carried out to normalize the expression data of $C g$-GnRH transcript. The relative level of $\mathrm{Cg}-\mathrm{GnRH}$ gene expression was calculated for one copy of the reference elongation factor $1 \alpha$ gene according to the following formula: $N=2^{(\mathrm{CtEF} 1 \alpha-\mathrm{CtCg} \text {-GnRH)}}$.

\subsection{Immunohistochemistry.}

Following dissection, nervous ganglia were fixed in Davidson's fixative during $24 \mathrm{~h}$. Fixed tissues were dehydrated, embedded in paraffin wax and sectioned at $5 \mu \mathrm{m}$. Deparafinized sections were incubated during $1 \mathrm{~h}$ at room temperature in buffer 1 consisting of 50mM Tris $\mathrm{pH} 7.4,150 \mathrm{mM} \mathrm{NaCl}, 5 \%$ skimmed milk. Sections were then carefully drained before overnight incubation with anti-oct-GnRH antiserum (kind gift of Pr. H. Minakata) diluted 1:800 in the buffer 2 ( $50 \mathrm{mM}$ TRIS pH 7.4, $150 \mathrm{mM} \mathrm{NaCl}, 1 \%$ skimmed milk, $0.05 \%$ Tween $20)$ in a moist chamber at $4^{\circ} \mathrm{C}$. Sections were washed twice $(10 \mathrm{~min}$ each) in buffer 2 , incubated for $1 \mathrm{~h}$ at room temperature with the horseradish peroxidase-conjugated polyclonal goat anti-rabbit IgG (Sigma-Aldrich) diluted 1:500 in buffer2, and then rinsed twice (10 min each) in buffer 2. Peroxidase activity was visualized, after a 10-min incubation in $200 \mu \mathrm{L}$ DAB (FastDAB, Sigma-Aldrich), as a brown precipitate. Sections were counterstained with light green, mounted in resin, and examined on a Nikon Eclipse 80i microscope coupled to a Nikon DXM1200-C camera. Controls were carried-out using preabsorbed antibodies in 
presence of an excess of oct-GnRH synthetic peptide (GeneCust, Luxemburg), or without primary or secondary antibodies. Potency of anti-oct-GnRH antiserum to specifically react with Cg-GnRH peptides was tested by immunotdoting of HPLC fractions of whole nonmature oyster extracts.

\section{Results}

\subsection{Identification of a GnRH-related peptides and their precursor.}

Peptidic extract of visceral ganglia fractionated by nano-LC was analyzed by mass spectrometry (MS). From MS/MS spectra, the amino acid sequences of two Cg-GnRH peptides of respective mass number $1359.63[\mathrm{M}+\mathrm{H}]^{+}$and $1417.64[\mathrm{M}+\mathrm{H}]^{+}$were determined

(Fig.1). The deduced sequences pQNYHFNSNGWQP-NH2 (Cg-GnRH-a) and pQNYHFNSNGWQPG (Cg-GnRH-G) were confirmed via the screening of both GnRH random library and GigasDatabase that led to the identification of the matching transcript (FU6OSJA01DBKYH). This full length transcript spans 453 bp including a 80 nucleotide leader sequence, a 273 bp ORF followed by a 100 nucleotide trailer and a poly(A) tail starting $20 \mathrm{bp}$ downstream to a (aataaa) consensus polyadenylation sequence. The cDNA encodes a precursor protein starting with an N-terminal hydrophobic signal peptide, probably cleaved Cterminally to $\mathrm{Ala}^{24}$ followed by a 11 amino acid $\mathrm{Cg}-\mathrm{GnRH}$ peptide separated from a GnRHassociated peptide (GAP) by a GKR sequence serving as combined amidation and prohormone convertase proteolytic signals (Fig.2A). Mature Cg-GnRHs exhibit a high degree of identity with other Lophotrochozoan GnRHs as well as some relatedness with vertebrate GnRHs, ecdysozoan adipokinetic hormones and Corazonin (Figure 2B). In contrast oyster GAP showed only $20.9 \%$ and $19.2 \%$ identity with those previously described in Octopus and Aplysia respectively (Figure 2C).

\subsection{Expression pattern of $\mathrm{Cg}-\mathrm{GnRH}$ transcript and $\mathrm{Cg}-\mathrm{GnRH}$ peptide in adult tissues.}


Spatial distribution of Cg-GnRH transcripts (Fig.3A) was determined by RT-qPCR using RNA samples from adult tissues. $C g$-GnRH transcripts were expressed almost exclusively at relatively high levels in the visceral ganglia. No significant expression of $\mathrm{Cg}-\mathrm{GnRH}$ transcript was detected in any of the other tissues. To investigate whether $\mathrm{Cg}-\mathrm{GnRH}$ transcripts were expressed differentially during the reproductive cycle, RT-qPCR was performed with RNA extracted from visceral ganglia collected from individuals at different stages of reproduction in both male and females (Figure 3B). Although no significant statistical variation was measured along the reproductive cycle, expression pattern appeared slightly different between males and females with a lower expression during vitellogenesis (stage 2) in females and, in contrast, a higher expression in males at this specific stage. Because the feeding status of the animal notably impacts the efficiency of gametogenesis in oyster [4], expression of Cg-GnRH transcripts was monitored in the visceral ganglia of fed and starved animals. Interestingly, $\mathrm{Cg}$ GnRH transcript levels were higher in fed animals though this increased expression was not statistically significant (Fig. 4).

The processing of a neuropeptide precursor usually results in end products being transported to the nerve terminals. Thus it was interesting to compare the tissue distribution of $\mathrm{Cg}-\mathrm{GnRH}$ transcripts with that of $\mathrm{Cg}-\mathrm{GnRH}$ peptides. To this end, HPLC fractions of different tissue extracts co-eluting with the synthetic Cg-GnRH peptides were analyzed by MALDI MS. CgGnRH peptides were unambiguously detected in the visceral ganglia fractions. In contract, no specific $\mathrm{Cg}-\mathrm{GnRH}$ signal could be identified in any of the other studied tissue fractions.

3.3 Immunohistochemical distribution of GnRH like peptides in the nervous system of Crassostrea gigas and Mytilus edulis.

Antibodies raised against octopus GnRH-like molecule (oct-GnRH), specifically labeled two HPLC fractions of whole non-mature oyster extracts, with retention times corresponding to 
those of $\mathrm{Cg}-\mathrm{GnRH}$ peptides. By immunocytochemistry, anti-oct-GnRH antiserum labeled scattered neurons within the visceral (Fig. 5A). In contrast to other bivalve mollusks, the central nervous system (CNS) of oysters which consists of only a pair of very tiny cerebral ganglia and a pair of coalesced visceral ganglia has been poorly studied. To gain an insight into the distribution of GnRH-like peptides in the CNS of bivalves, a parallel investigation was carried out using sections of the ganglia of the mussel Mytilus edulis. Both cerebral and pedal ganglia displayed a strong signal in pyriform neurons within the cortex or at the vicinity of the neuropile (Fig. 5B and C). These cells display the features of type a1 neurosecretory cells described previously [13]. In addition, axon fibers were also strongly immunoreactive.

\section{Discussion.}

For more than a decade, the occurrence of functionally active GnRH-related peptides was strongly suggested in bivalve mollusks [25]. The present study describes for the first time the molecular identification of GnRH-related peptides and its peptide precursor from the Pacific oyster Crassostrea gigas. Oyster GnRH precursor exhibits the typical architecture of all identified vertebrate and mollusk GnRH precursors consisting of a signal peptide, a single GnRH sequence separated from GnRH-associated peptide by cleavage at a dibasic processing site. This cleavage yields two GnRH forms; Cg-GnRH-G a non-amidated dodecapeptide with the C-terminal "Pro-Gly" motif and Cg-GnRH-a, the corresponding amidated peptide whose terminal glycine catalyzed by a peptidyl glycine- $\alpha$-amidating mono-oxygenase provides the amide group. The newly discovered peptides appear highly conserved in the mollusk phylum (Figure 2B). All the mollusk peptides, including the Japanese scallop (Patinopecten yessoensis) new peptide retrieved from EST databases, exhibit the typical extra dipeptide insertion after the N-terminal pyro-glutamate residue of all lophotrochozoan GnRHs. This extra "Asn-Tyr" dipeptide in oct-GnRH was found requisite for activity and receptor binding 
and explained the weak or no activity of most vertebrate GnRHs in octopus [17]. Precisely, this key dipeptide insertion shows subtle sequence variability among lophotrochozoan peptides and might support species specific activity discrimination. The core sequence is strictly conserved among lophotrochozoan GnRHs and displays uneven degree of identity with deuterostome GnRHs, adipokinetic hormones (AKHs) and corazonin, two ecdysozoan peptide families known to signal via GnRH receptor orthologues [3, 18, 31]. This stresses the likely shared ancestry of these peptide families and co-evolution with their receptors [28]. Though critical for receptor binding, the highly conserved C-terminal (Pro-Gly-amide) motif of vertebrate GnRHs [21] was only found in oct-GnRH and in the non-amidated form of CgGnRH-G. Presence of this motif probably explains the gonadotropin-releasing activity of octGnRH on quail anterior pituitary cells [15]. Variability of this motif may also account for the disparity of results obtained in mollusks by immunochemical methods based on the use of antibodies against vertebrate GnRHs $[5,39]$ or in term of potency of the distinct vertebrate GnRHs to activate target cells [25].

In contrast to the GnRH peptide, the long companion C-terminal peptide generated from the precursor, also named GnRH-associated peptide (GAP) does not exhibit sequence conservation with vertebrate GAPs. Despite moderate identity among mollusk GAPs, the pattern of cysteine residues, known to be critical for strengthening the tertiary structure of secreted peptides, was strictly conserved. This suggests that GAP might be functional in mollusks but with a probable accessory role that would explain the lower selective pressure during evolution.

Previous studies in mollusks have demonstrated a wide distribution of GnRH transcripts in the central nervous system and accessory sex organs [38] or oocytes [6]. In contrast, oyster Cg-GnRH transcripts were highly and exclusively expressed in the visceral ganglia. This pattern of expression is somewhat reminiscent of the major expression of GnRH-II in 
vertebrate midbrain and octopus brain and implies that $\mathrm{Cg}-\mathrm{GnRH}$ would serve as neural regulator in the CNS as was suggested for oct-GnRH [14]. In Octopus, endogenous oct-GnRH acts as a multifunctional modulatory factor in memory processing, sensory, movement, autonomic functions and feeding [22]. Ap-GnRH in Aplysia was also shown to modulate a wide range of behavioral events such as parapodial opening and inhibition of feeding [33]. The higher expression of $\mathrm{Cg}-\mathrm{GnRH}$ transcripts in fed oysters compared to starved oysters also coincides with a role in the control of feeding. With the experimental demonstration that GnRH-II is a potent anorexigenic factor in vertebrates [20], inhibition of feeding now emerges as a likely GnRH ancestral function shared by both vertebrates and Protostoma. In vertebrates, it has been proposed that GnRH-II would coordinate changes in nutrition with reproductive status [32]. As storage metabolism in oysters is closely associated with reproduction [2]; it is thus intriguing to notice changes in expression of $\mathrm{Cg}-\mathrm{GnRH}$ transcripts in oyster CNS along the reproductive cycle. Although careful additional investigations should be developed, $\mathrm{Cg}$-GnRH appears as an good candidate neuropeptide to synchronize nutritional status with energy requirements during reproduction in oyster as was already suggested in vertebrates [32].

The failure to reveal mature $\mathrm{Cg}-\mathrm{GnRH}$ peptide in any peripheral tissues of the oyster suggests that nerve terminals controlling the activity of these tissues do not release the peptide locally except in amounts not detectable with the method applied. As was proposed for oct-GnRH [15], the possibility that Cg-GnRH would be released into the circulation and work as a neurohomone to regulate peripheral organs cannot be rule-out. This suggestion is in agreement with the demonstration of oct-GnRH immunoreactive neurosecretory cells in the nervous ganglia of $M$. edulis and conforms to previous studies demonstrating the activity of vertebrate GnRHs on reproductive or non reproductive target cells in bivalve mollusks [23, 25]. Another key point that argues for the endocrine activity of Cg-GnRHs in C. gigas is the 
occurrence of GnRH receptor orthologues present either specifically in the gonad [29] or in various peripheral organs [30]. Expression of these receptors in the gonads is consistent with a reproductive modulating activity of $\mathrm{Cg}-\mathrm{GnRHs}$ as putative ligands. Similar involvement in reproductive-related processes was also put forward for oct-GnRH in Octopus [17] though no reproductive activity could be demonstrated for ap-GnRH in Aplysia [33]. On the other hand, the wide tissue distribution of some oyster GnRH receptor forms [30] also implies additional non-reproductive regulatory activities. It remains to be proven functionally using reverse endocrinology methods [18] whether oyster receptors are the true targets for Cg-GnRHs. Although C. gigas receptors most likely bind different sets of peptides [30] they appear phylogenetically closer to the ecdysozoan $\mathrm{AKH}$ receptors than to the functionally characterized octopus GnRH receptor which clusters with insect corazonin receptors. AKHs, the insect metabolic hormones that mobilize energy substrates during energy-consuming activities [9] have been shown to affect reproduction processes in C. elegans [18] and plausibly to play a role in oocyte maturation in the fall armyworm [1]. The recent identification of true AKH-related neuropeptides in C. gigas (unpublished results) and in other classes of mollusks [28] demonstrates that the paths connecting the GnRH, AKH and corazonin families of peptides through metazoan evolution is more complex than formerly anticipated.

\section{Figure legends.}

Figure 1: Mass analyses of $\mathrm{Cg}-\mathrm{GnRH}$ peptides. $\mathrm{MS}$ and MS-MS spectra of pQNYHFSNGWQPa (A) and pQNYHFSNGWQPG (B) peptides. Mass and Mascot identification from MSMS spectra confirm the sequences and the existence of an N-terminal pyroglutamate (A and B) and a C-terminal amide (A) 
Figure 2: A- Nucleotide sequence of the cDNA encoding a $\mathrm{Cg}-\mathrm{GnRH}$ precursor in Crassostrea gigas and the deduced amino acid sequence. Putative signal peptide is indicated in italics. Potential combined amidation/proteolytic processing site is shaded in grey. The predicted mature peptides are underlined and shown in boldface. The consensus polyadenylation sequence is underlined. B- Alignment of GnRH, AKH and Corazonin peptide family members. Sequences are compared to $\mathrm{Cg}-\mathrm{GnRH}-\mathrm{a}$, identical residues are shaded in black, and similar residues in grey. Peptide sequences are deduced from the cDNA sequences of Crassostrea gigas (FQ666028, FU6OSJA01DBKYH), Mizuhopecten yessoensis (BAH47639.1) (* new sequence), Aplysia californica (ABW82703.1), Octopus vulgaris (AB037165), Lottia gigantea (FC805607 and FC796606), Strongylocentrotus purpuratus (XP_800179), AKH sequences from Caenorhabditis elegans (AAC26928), Drosophila melanogaster (P61855), Red Pigment Concentrating Hormone (RPCH) from Carcinus maenas (Q26324) and Corazonin (Crz) sequence from Drosophila melanogaster (AJ851893). C- Alignment of GnRH-associated peptides (GAP) deduced from Crassostrea, Octopus and Aplysia GnRH precursors.

Figure 3: Differential Cg-GnRH gene expression in adult tissues (A) and in the visceral ganglia of male (M) and female (F) individuals at different stages of reproduction (B) of $C$. gigas measured by real-time quantitative RT-PCR. Each value is the mean + S.E. of 5 pools of 6 visceral ganglia. Expression levels are calculated as the number of copies of $\mathrm{Cg}-\mathrm{GnRH}$ transcript per copy of elongation factor $1 \alpha(\mathrm{EF} 1 \alpha)$ mRNA. Stage 0: sexual resting stage, Stage 1: gonial multiplication stage, stage 2: tubule development and maturation stage, stage 3: sexual maturity stage. 
Figure 4: Differential $\mathrm{Cg}-\mathrm{GnRH}$ gene expression in visceral ganglia of fasted and fed individuals of $C$. gigas. Each value is the mean + S.E. of 15 individual visceral ganglia. Expression levels are calculated as the number of copies of Gg-GnRH transcript per copy of elongation factor $1 \alpha(\mathrm{EF} 1 \alpha)$ mRNA. Results were statistically tested with a one-way ANOVA, $p<0,05$. No significant statistical difference was observed.

Figure 5: GnRH-like immunoreactivity in the central nervous system of Crassostrea gigas (A) and Mytilus edulis (B, C) using anti oct-GnRH. A: Sections of visceral ganglia: (A1) control section, (A3/4) few scattered immunoreactive neurons and (A2) nerve fibers. B: sections of cerebral ganglia: (B1) control section, (B2/3) Immunopositive sections showing immunoreactive al neurosecretory cells within the cortical region (c), insert (higher magnification). A prominent fiber tract (FT) at the vicinity of the neuropile (N). C: sections of pedal ganglia. (C1): control section, (C2/3) sections showing immunopositive typical pyriform type a1 neurosecretory cells as well as immunorective axon fibers.

\section{Acknowledgments.}

The authors thank Pr. H. Minakata (Osaka, Japan) for providing us with anti-oct-GnRH antiserum and the staff of the experimental hatchery of Argenton (France) for the trophic conditioning of the oysters. This work was funded by the ANR project "Gametogenes" (ANR-08-GENM-041). L. Bigot was funded by Ifremer and a Région Basse-Normandie doctoral grant.

References 
[1] Abdel-Latief M, Hoffmann KH. The adipokinetic hormones in the fall armyworm, Spodoptera frugiperda: cDNA cloning, quantitative real time RT-PCR analysis, and gene specific localization. Insect Biochem Mol Biol. 2007;37:999-1014.

[2] Berthelin C, Kellner K, Mathieu M. Storage metabolism in the Pacific oyster (Crassostrea gigas) in relation to summer mortalities and reproductive cycle (west coast of France). Comp Biochem Physiol B Biochem Mol Biol. 2000;125:359-69.

[3] Cazzamali G, Saxild N, Grimmelikhuijzen C. Molecular cloning and functional expression of a Drosophila corazonin receptor. Biochem Biophys Res Commun. 2002;298:31-6.

[4] Chavez-Villalba J, Cochard JC, Le Pennec M, Barret J, Enriquez-Diaz MR, CaceresMartinez C. Effects of temperature and feeding regimes on gametogenesis and larval production in the oyster Crassostrea gigas. Journal of Shellfish Research. 2003;22:721-31.

[5] Di Cosmo A, Di Cristo C. Neuropeptidergic control of the optic gland of Octopus vulgaris: FMRF-amide and GnRH immunoreactivity. J Comp Neurol. 1998;398:1-12.

[6] Di Cristo C, De Lisa E, Di Cosmo A. GnRH in the brain and ovary of Sepia officinalis. Peptides. 2009;30:531-7.

[7] Ernande B, Boudry P, Clobert J, Haure J. Plasticity in resource allocation based life history traits in the Pacific oyster, Crassostrea gigas. I. Spatial variation in food abundance. J Evol Biol. 2004;17:342-56.

[8] Fleury E, Huvet A, Lelong C, de Lorgeril J, Boulo V, Gueguen Y, et al. Generation and analysis of a 29,745 unique Expressed Sequence Tags from the Pacific oyster (Crassostrea gigas) assembled into a publicly accessible database: the GigasDatabase. BMC Genomics. $2009 ; 10: 341$.

[9] Gade G. Peptides of the adipokinetic hormone/red pigment-concentrating hormone family: a new take on biodiversity. Ann N Y Acad Sci. 2009;1163:125-36. 
[10] Gorbman A, Whiteley A, Kavanaugh S. Pheromonal stimulation of spawning release of gametes by gonadotropin releasing hormone in the chiton, Mopalia sp. Gen Comp Endocrinol. 2003;131:62-5.

[11] Guillemin R. Peptides in the brain: the new endocrinology of the neuron. Science. 1978;202:390-402.

[12] Huvet A, Normand J, Fleury E, Quillien V, Fabioux C, Boudry P. Reproductive effort of Pacific oysters: a trait associated with susceptibility to summer mortality. Aquaculture. 2010;304:95-9.

[13] Illanes-Bucher AJW, Lubet P. Etude de l'activité neurosécrétrice au cours du cycle sexuel annuel de la moule Mytilus edulis L. Bull Soc Zool France. 1980;105:141-51.

[14] Iwakoshi-Ukena E, Ukena K, Takuwa-Kuroda K, Kanda A, Tsutsui K, Minakata H. Expression and distribution of octopus gonadotropin-releasing hormone in the central nervous system and peripheral organs of the octopus (Octopus vulgaris) by in situ hybridization and immunohistochemistry. J Comp Neurol. 2004;477:310-23.

[15] Iwakoshi E, Takuwa-Kuroda K, Fujisawa Y, Hisada M, Ukena K, Tsutsui K, et al. Isolation and characterization of a GnRH-like peptide from Octopus vulgaris. Biochem Biophys Res Commun. 2002;291:1187-93.

[16] Kah O, Lethimonier C, Somoza G, Guilgur LG, Vaillant C, Lareyre JJ. GnRH and GnRH receptors in metazoa: a historical, comparative, and evolutive perspective. Gen Comp Endocrinol. 2007;153:346-64.

[17] Kanda A, Takahashi T, Satake H, Minakata H. Molecular and functional characterization of a novel gonadotropin-releasing-hormone receptor isolated from the common octopus (Octopus vulgaris). Biochem J. 2006;395:125-35. 
[18] Lindemans M, Liu F, Janssen T, Husson SJ, Mertens I, Gade G, et al. Adipokinetic hormone signaling through the gonadotropin-releasing hormone receptor modulates egglaying in Caenorhabditis elegans. Proc Natl Acad Sci U S A. 2009;106:1642-7.

[19] Loumaye E, Thorner J, Catt KJ. Yeast mating pheromone activates mammalian gonadotrophs: evolutionary conservation of a reproductive hormone? Science. $1982 ; 218: 1323-5$.

[20] Matsuda K, Nakamura K, Shimakura S, Miura T, Kageyama H, Uchiyama M, et al. Inhibitory effect of chicken gonadotropin-releasing hormone II on food intake in the goldfish, Carassius auratus. Horm Behav. 2008;54:83-9.

[21] Millar RP. GnRHs and GnRH receptors. Anim Reprod Sci. 2005;88:5-28.

[22] Minakata H, Shigeno S, Kano N, Haraguchi S, Osugi T, Tsutsui K. Octopus gonadotrophin-releasing hormone: a multifunctional peptide in the endocrine and nervous systems of the cephalopod. J Neuroendocrinol. 2009;21:322-6.

[23] Nakamura S, Osada M, Kijima A. Involvement of GnRH neuron in the spermatogonial proliferation of the scallop, Patinopecten yessoensiss. Mol Reprod Dev. 2007;74:108-15.

[24] Park Y, Kim YJ, Adams ME. Identification of $G$ protein-coupled receptors for Drosophila PRXamide peptides, CCAP, corazonin, and AKH supports a theory of ligandreceptor coevolution. Proc Natl Acad Sci U S A. 2002;99:11423-8.

[25] Pazos AJ, Mathieu M. Effects of five natural gonadotropin-releasing hormones on cell suspensions of marine bivalve gonad: stimulation of gonial DNA synthesis. Gen Comp Endocrinol. 1999;113:112-20.

[26] Piferrer F, Beaumont AR, Falguière J-C, Flajšhans M, Haffray P, Colombo L. Polyploid fish and shellfish: Production, biology and applications to aquaculture for performance improvement and genetic containment. Aquaculture. 2009;293:125-56. 
[27] Ramakrishnappa N, Rajamahendran R, Lin YM, Leung PC. GnRH in non-hypothalamic reproductive tissues. Anim Reprod Sci. 2005;88:95-113.

[28] Roch GJ, Busby ER, Sherwood NM. Evolution of GnRH: diving deeper. Gen Comp Endocrinol.171:1-16.

[29] Rodet F, Lelong C, Dubos MP, Costil K, Favrel P. Molecular cloning of a molluscan gonadotropin-releasing hormone receptor orthologue specifically expressed in the gonad. Biochim Biophys Acta. 2005;1730:187-95.

[30] Rodet F, Lelong C, Dubos MP, Favrel P. Alternative splicing of a single precursor mRNA generates two subtypes of Gonadotropin-Releasing Hormone receptor orthologues and their variants in the bivalve mollusc Crassostrea gigas. Gene. 2008;414:1-9.

[31] Staubli F, Jorgensen TJ, Cazzamali G, Williamson M, Lenz C, Sondergaard L, et al. Molecular identification of the insect adipokinetic hormone receptors. Proc Natl Acad Sci U S A. 2002;99:3446-51.

[32] Temple JL, Millar RP, Rissman EF. An evolutionarily conserved form of gonadotropinreleasing hormone coordinates energy and reproductive behavior. Endocrinology. 2003;144:13-9.

[33] Tsai PS, Sun B, Rochester JR, Wayne NL. Gonadotropin-releasing hormone-like molecule is not an acute reproductive activator in the gastropod, Aplysia californica. Gen Comp Endocrinol.166:280-8.

[34] Tsai PS, Zhang L. The emergence and loss of gonadotropin-releasing hormone in protostomes: orthology, phylogeny, structure, and function. Biol Reprod. 2008;79:798-805.

[35] Twan WH, Hwang JS, Lee YH, Jeng SR, Yueh WS, Tung YH, et al. The presence and ancestral role of gonadotropin-releasing hormone in the reproduction of scleractinian coral, Euphyllia ancora. Endocrinology. 2006;147:397-406. 
[36] Veenstra JA. Neurohormones and neuropeptides encoded by the genome of Lottia gigantea, with reference to other mollusks and insects. Gen Comp Endocrinol. 2010;167:86103.

[37] Young KG, Chang JP, Goldberg JI. Gonadotropin-releasing hormone neuronal system of the freshwater snails Helisoma trivolvis and Lymnaea stagnalis: possible involvement in reproduction. J Comp Neurol. 1999;404:427-37.

[38] Zhang L, Tello JA, Zhang W, Tsai PS. Molecular cloning, expression pattern, and immunocytochemical localization of a gonadotropin-releasing hormone-like molecule in the gastropod mollusk, Aplysia californica. Gen Comp Endocrinol. 2008;156:201-9.

[39] Zhang L, Wayne NL, Sherwood NM, Postigo HR, Tsai PS. Biological and immunological characterization of multiple $\mathrm{GnRH}$ in an opisthobranch mollusk, Aplysia californica. Gen Comp Endocrinol. 2000;118:77-89. 
A

aagctagtggtatcaacgcagagtggtcattacggccggggcccattcaccacacagcata 61 ggaagtgaaacatacaagaATGAAGGTTTCGCCATGCACACAAGTGATAGTGATGGTTTTA 122 $\begin{array}{lllllllllllllll}M & K & V & S & P & C & T & Q & V & I & V & M & V & L & 14\end{array}$

ACACTTGGATTGCTGTGTGAAGTCCATGCCCAAAATTACCACTTCAGCAATGGATGGCAG 182 $\begin{array}{lllllllllllllllllllll}T & L & G & L & L & C & E & V & H & A & \mathbf{Q} & \mathbf{N} & \mathbf{Y} & \mathbf{H} & \mathbf{F} & \mathbf{S} & \mathbf{N} & \mathbf{G} & \mathbf{W} & \mathbf{Q} & \mathbf{3 4}\end{array}$ CCCGGCAAGAGAAGCTACCGAGGGTGTACTGTACGGCCAGAAATACGCTCCATTTTAATC 242 $\begin{array}{lllllllllllllllllllll}\mathbf{P} & \mathrm{G} & \mathrm{K} & \mathrm{R} & \mathrm{S} & \mathrm{Y} & \mathrm{R} & \mathrm{G} & \mathrm{C} & \mathrm{T} & \mathrm{V} & \mathrm{R} & \mathrm{P} & \mathrm{E} & \mathrm{I} & \mathrm{R} & \mathrm{S} & \mathrm{I} & \mathrm{L} & \mathrm{I} & \mathbf{5 4}\end{array}$ AAAATCATAGAGGATGAAGTTGAAAGAATACAAAAATGTTCACATTCTAACATTGAAGAT 302

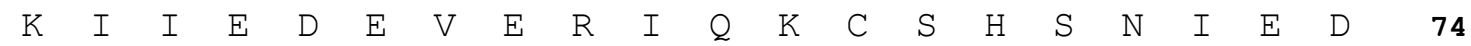
GTTTTCTCATTAATACAGGAAAAAACTGGTGTGGATGCCCGTGAAGTGTAAttagagaag 362 $\begin{array}{llllllllllllllllll}V & F & S & L & I & Q & E & K & T & G & V & D & A & R & E & V & * & 90\end{array}$ atgacattagctctgcaggacagatggacagacaatgaatgagtttagtgtgatgcagaa 422 tatttcaataaatttttattctctcaaagt $(a)_{n}$

\section{Figure 2:}


C. gigas GnRH-a

C. gigas GnRH-G

$M$. yessoensis* GnRH

O. vulgaris $\mathrm{GnRH}$

A. californica GnRH

L. gigantea GnRH

C. teleta $\mathrm{GnRH}$

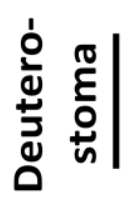

G. gallus GnRH-I

G. gallus GnRH-II

$S$. purpuratus* GnRH

C. elegans $\mathrm{AKH}$

D. melanogaster AKH

C. borealis RPCH

L. migratoria corazonin
PQNYHFSNGWQP-amide PQNYHFSNGWQPG

PQNFHYSNGWQP-amide PQNYHFSNGWHPGamide PQNYHFSNGWYA-amide PQHYHFSNGWKS-amide PQAYHFSNGWKS-amide

PQ--HWSYGLQPGamide PQ--HWSHGWYPGamide PQVHERFS GKRPGamide

PQ-MTETDQWTT--

PQ-LTESPDN---amide PQ-LNFSPGW---amide

PQTSQYSHGWTN-amide

C

Figure 2 
A

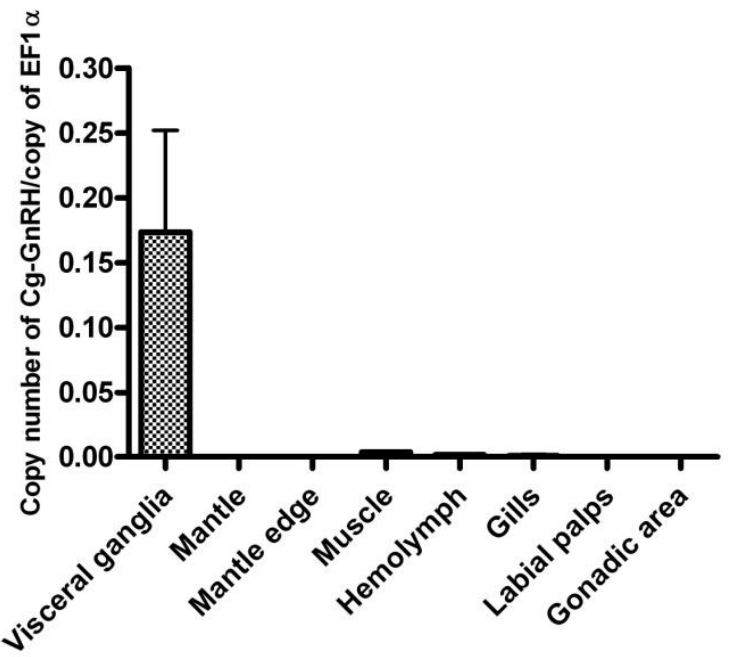

B

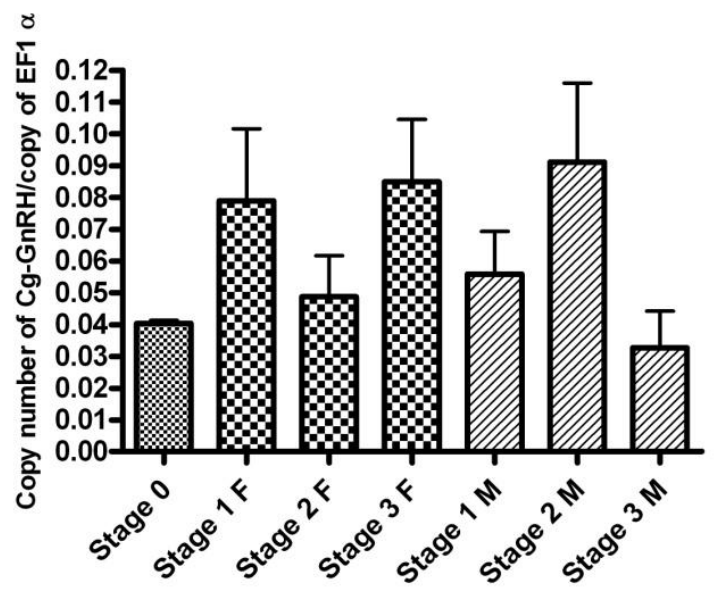

Figure 3. 


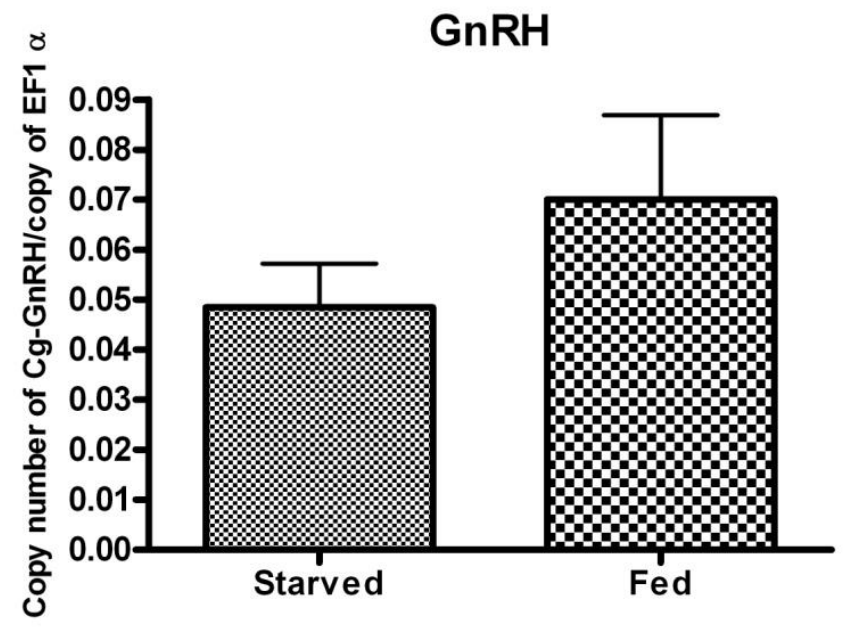

Figure 4 : 


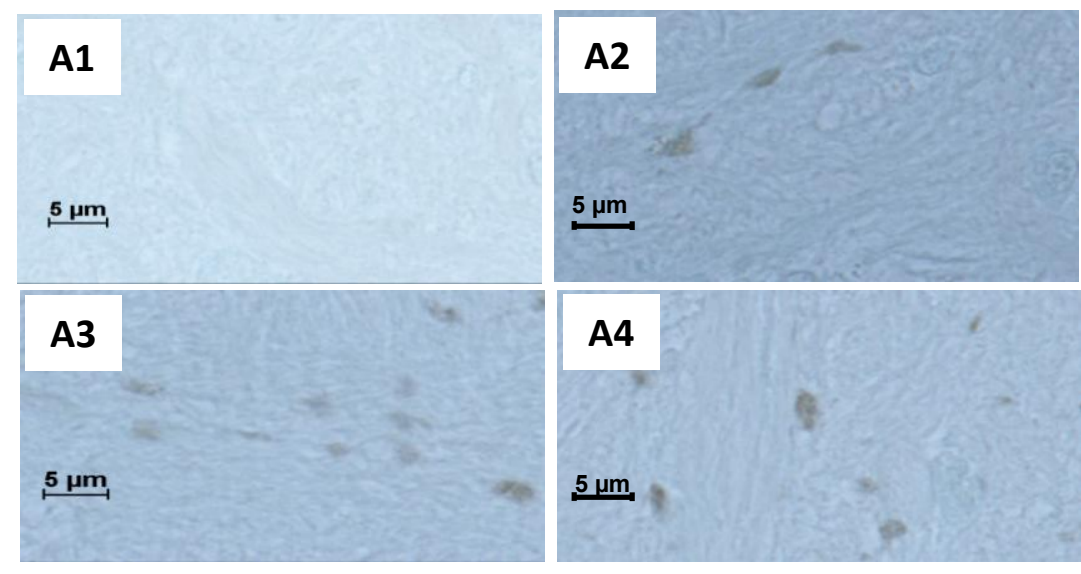

Figure 5
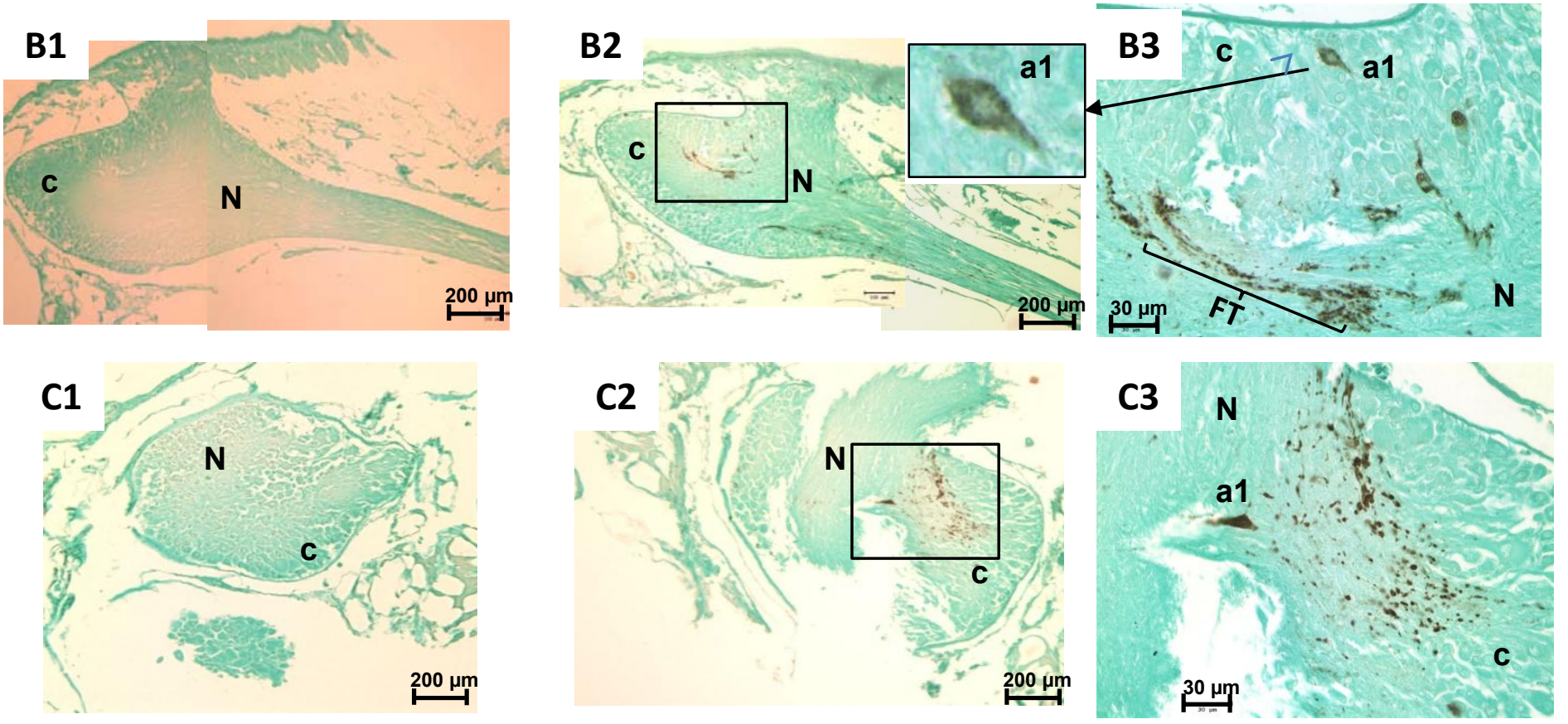